Ambiente \& Água - An Interdisciplinary Journal of Applied Science
ISSN 1980-993X - doi:10.4136/1980-993X
www.ambi-agua.net
E-mail: ambi.agua@gmail.com

\title{
Wastewater treatment using adsorption process in column for agricultural purposes
}

\author{
ARTICLES doi:10.4136/ambi-agua.2178
}

Received: 03 Sep. 2017; Accepted: 01 Dec. 2018

\author{
Flávia Rhuana Pereira Sales ${ }^{1 *}$; ; Reynaldo Borges Galvão Serra ${ }^{1}$; \\ Gesivaldo Jesus Alves de Figueirêdo ${ }^{1}$; ; Paulo Henrique Almeida da Hora ${ }^{2}{ }^{\circledR}$; \\ Antonio Cícero de Sousa ${ }^{1}$ (iD \\ ${ }^{1}$ Instituto Federal de Educação, Ciência e Tecnologia da Paraíba (IFPB), João Pessoa, PB, Brasil \\ Departamento de Química. E-mail: flavia.rhuana@outlook.com, reynaldoifpb@hotmail.com, \\ gesivaldo.figueiredo@ifpb.edu.br, antonio.cicero@ifpb.edu.br \\ ${ }^{2}$ Universidade Federal da Paraíba (UFPB), João Pessoa, PB, Brasil \\ Programa de Pós-Graduação em Ciência e Engenharia de Materiais (PPCEM). \\ E-mail: pauloalmeidaeng@gmail.com \\ *Corresponding author
}

\begin{abstract}
Water is essential for life, important for the ecosystem and it is in great demand due to its scarcity. This study explored the reuse of the wastewater of the Water Treatment Plant in Gramame for agricultural purposes. A qualitative and quantitative investigation of the effluent was carried out through the characterization of its physical and chemical parameters, comparing the results to what is allowed by the current legislation, CONAMA Resolution 357/2005. After this process, the activated charcoal of coco-da-baia mesocarp, adsorbent material, was prepared and tested in a filter system in a column with a continuous flow and ascendant entrance, in which the kinetic effect was evaluated. This technique was evaluated by correlating the reduced values in the adsorption material, respecting the initial effluent concentration, obtaining a reduction of $50 \%$ in the hardness, $87.5 \%$ in chloride and $66.6 \%$ in acidity. These results verified the adequacy of the technique in potential hydrogenation $(\mathrm{pH})$ and abrupt reduction of color and turbidity. This treatment is suggested to qualify the effluent for use in agricultural, safe for humans and the environment. The adsorbent substrate efficiency was verified by correlating it with the Thomas isothermal model.
\end{abstract}

Keywords: activated charcoal of the coco-da-baia mesocarp, adsorption process, reuse of water.

\section{Tratamento de águas residuárias utilizando processo de adsorção em coluna para fins agrícolas}

\section{RESUMO}

A água é um recurso essencial para vida, de extrema relevância para o ecossistema e encontra-se com várias problemáticas, entre elas a escassez. Por conta disso, o presente estudo foi desenvolvido a fim de propiciar a reutilização da água residuária da Estação de Tratamento de Água de Gramame para fins agrícolas. Assim, foi realizada a investigação qualitativa e quantitativa deste efluente, por meio da caracterização deste, considerando os parâmetros físicos e químicos, em que os resultados obtidos foram comparados com a legislação vigente, 
resolução CONAMA n ${ }^{\circ}$ 357/2005. Após este processo, o carvão ativado do mesocarpo do cocoda-baía, material adsorvente, foi preparado e testado em um sistema de filtração em coluna com fluxo contínuo e entrada ascendente, na qual, o efeito da cinética foi avaliado. Com isso a técnica foi avaliada correlacionando os valores reduzidos na adsorção em relação a concentração inicial do efluente, obtendo redução de 50\% na dureza, 87,5\% em cloretos e $66,6 \%$ na acidez, estes resultados contribuíram na adequação do potencial hidrogeniônico $(\mathrm{pH})$, redução abrupta de cor e turbidez. Com isso, vislumbra-se ofertar esta técnica de tratamento para qualificação do efluente no âmbito agrícola com segurança e adequação para o homem e o meio ambiente. A eficiência do substrato adsorvente, foi verificada correlacionando-a com o modelo isotérmico de Thomas.

Palavras-chave: processo de adsorção, qualidade de água, substrato adsorvente.

\section{INTRODUCTION}

Water is a natural resource that is crucial for the survival and equilibrium of the ecosystem. It is used in many fields and for many purposes. With the passage of time, this resource has become progressively more scarce in urban, industrial and agricultural development, mainly in arid and semiarid regions.

Not only these regions suffer from water scarcity, however. Some regions have abundant water resources but in insufficient quantity to satisfy the excessive demand, which leads to restrictions on consumption. Thus, administrative agencies of water resources and the academic community are searching for new sources of water supply as well as technology that permits water waste reduction. This includes making users aware of water issues, rationalizing water use, and increasing the available water for agricultural use.

According to Telles and Costa (2010, p. 155), water reuse is "considered an intelligent option for the world market, where the need of this technology application... is in the very concept of sustainability of environmental resources". Moreover, there are plenty of water bodies appropriate for reuse, whether contaminated, polluted or clean.

Water can be contaminated by a large variety of substances, to include chemical, physical/biological agents. An example of this is the wastewater from Water Treatment Plants (WTPs). A WTP applies processes to raw water, resulting in a final product (treated water). Raw water is treated with different chemical reagents, which produce residue. According to Achon et al. (2008, p. 54), "the residues produced from WTPs are mainly the water from filter cleaning and sludge".

Wastewater from the process mentioned before are the water from the cleaning, filters, settling tanks, and solution preparation tanks. For this water to be reused in the agricultural sector, it is necessary to check the physical, chemical and bacteriological conditions, patterns and requirements established by the Resolution of the National Counseling of the Environment (CONAMA) in number 357 (CONAMA, 2005).

There are several processes available for water treatment. Most of them are economically unviable, such as: oxidation, reverse osmosis, ion exchange, electrodialysis, electrolysis. These processes can cost from US\$ 10 to US\$ 450 per cubic meter of treated water. The use of adsorption technology, however, lowers this cost to US\$ 5.0 to US\$200 per cubic meter of water (Ali et al., 2012). The adsorption technique is defined as a process of transference of mass where one or more substances (adsorbate) present in a gaseous or liquid stream is transferred in a selective way to the surface of a porous solid (adsorbent).

The adsorption technique is widely used in the treatment of water, being a technologically and economically viable technology, able to remove organic pollutants with efficiency of $99.9 \%$ (Ali et al., 2012). 
From this perspective, the column adsorption process can be used because it is determined by a dynamic process that involves liquid flow and mass transference from an ionic exchange. The application of the adsorptive process in a column has been studied in several matrices (Ali, 2010; De Franco et al., 2018; Do Nascimento et al., 2014; Yaumi et al., 2018; Matsubara and Coelho, 2018; Monteiro, 2017). In addition, an adsorptive column allows a more efficient use of the adsorbent, since the dynamic system enables an evaluation of the material saturation in relation to the time, space and length of the adsorption column (Sousa Neto, 2012).

A popular means of evaluating an adsorbent in a column system, according to Yang et al. (2015), is Thomas's model. Yang notes that "traditionally this model is used to determine the maximum capacity of adsorption of an adsorbent in a continuous system".

In this perspective, the adsorbent often used is activated carbon because it has the appropriate porous inner surfaces for the access of gas/liquid. Along the same line, Silva et al. (2015, p. 654) explained that "the charcoal prepared from the coconut shell and thermally activated presents excellent capacity for adsorption as adsorbent due to the presence of basic functional groups, such as carboxylics, hydroxyls and lactones". Also,coal has been used for the treatment of effluents since 1940 as one of the main adsorbents due to its great adsorption capacity (Ali, 2010).

Finally, research must be accompanied by alternative technologies directed towards wastewater reuse. An adsorption process in column and continuous flow with the activated carbon of Coco-da-baia Mesocarp (Cocos nucífera L.) was evaluated for the purpose of treating wastewater from a WTP located in João Pessoa-PB, according to the conditions stated by the Resolution of CONAMA, number 357. The treated water was then used for agricultural processes, competing a sustainable action.

\section{MATERIALS AND METHODS}

Selection of the study area was made by visiting the Water Treatment Plant in Gramame located in João Pessoa - PB, which is responsible for most of the public water provision of João Pessoa. The WTP had not previously used the treatment process to take advantage of its effluent.

The methodology used to analyze the data was quantitative, that "emphasizes numbers (or information convertible into numbers) to verify the existence or not of the consequences ... The data are analyzed with Statistics support (including multivariate) or other mathematical techniques" (Dalfovo et al., 2008, p. 7).

First, wastewater samples were collected with the purpose of describing them according to the Resolution Number 357 of CONAMA, through an adsorption process in column with continuous flow in order to be used in the agricultural fields.

The physical-chemical analyses that were made were: physical parameters (temperature; color; smell) and chemical (turbidity, hydrogenionic potential - $\mathrm{pH}$; carbonic acidity and total; calcium hardness, magnesia and total; conductivity; alkalinity; chlorides).

All the processes of preparation and analyses of the contemplated parameters of the research conformed to what is described in "Standard Methods for the Examination of Water and Wastewater" (APHA, 2005).

The preparation of the charcoal substrate was made as follows: washing of the raw material (coco-da-baia mesocarp) and then exposing it to the sun. The contact surface of the material was then prepared using a hammer, to crush, sieve and char the husk/shell in a rotating electric oven with a fixed recipient reactor. The material was reduced to fibers in a grinder and exposed to high temperatures in order to increase the porosity and efficiency of the mesocarp. After this step, the charcoal of the mesocarp was obtained through a process of activation with phosphoric acid.

\section{IPABH}

Rev. Ambient. Água vol. 14 n. 1, e2178 - Taubaté 2018 
In the chemical activation process, the fibers were immersed for two hours in phosphoric acid at a ratio of $90 \%\left(\mathrm{H}_{3} \mathrm{PO}_{4}\right.$ mass / fiber mass). The fibers were then placed in a rotary electric oven (CHINO) at a temperature of $1173 \mathrm{~K}\left(900^{\circ} \mathrm{C}\right)$ for five hours for carbonization. In the final stage, the charcoal was washed various times with distilled water at $100^{\circ} \mathrm{C}$ to remove the excess reagent used in the chemical activation until the $\mathrm{pH}$ of the water had reached around 7.0 (Cambuim, 2009). Finally, the charcoal was dried (in an oven at $110^{\circ} \mathrm{C}$ ) for 24 hours, macerated and sieved in a 200 mesh.

Afterwards, investigation began of the capacity of the coco-da-baia mesocarp's activated charcoal's adsorption in a column with continuous flow weighing 0.5 grams. The column was made of a glass recipient, $5 \mathrm{~cm}$ in diameter, containing sand, gravel, grit and the substrate, organized respectively in an initial layer of gravel, grit, thick sand, thin sand, activated carbon, thin sand and thick sand. It is important to highlight that all this material had been washed with hydrochloric acid $(\mathrm{HCl})$ at $10 \%$.

For the adsorption process, about 50 liters of the wastewater sample was poured through the adsorbent of the continuous flow column with an ascending entrance, for 7 hours at a flow of 1.5 L/hr. Eight samples were collected at 30, 60, 120, 180, 240, 300, 360 and 420 minutes.

After the collection, the samples were submitted to physical-chemical analyses (temperature; color; smell, turbidity, hydrogen ionization potential - $\mathrm{pH}$; carbonic acidity and total; calcium hardness, magnesia and total; conductivity; alkalinity; chlorides) with the objective of verifying the quantity each element that had been adsorbed.

When this was finished, the results were organized in a chart to make graphics, in order to better observe the adsorption behavior after each specific contact time. The results were then adjusted to the isotherm adsorption model established by Thomas to prove and set the maximum capacity of the adsorbent adsorption studied.

\section{RESULTS AND DISCUSSION}

Human activities promote high levels of pollution, according to the National Inventory of Water Quality generated by the U.S Environmental Protection Agency, which reported that $45 \%$ of the rivers, $47 \%$ of the lakes and $32 \%$ of the estuaries in the US. are already polluted. Similarly, in Brazil, the water captured by the WTP's comes from rivers, making chemical treatment essential and creating effluents. As most of the effluents are thrown away without treatment, our aim was to use them for agriculture through an adsorption treatment with charcoal made from Coco-da-baia mesocarp.

The effluent, water from cleaning filters of the WTP in Gramame was collected and described. High quantities of turbidity and color were found, which had been expected due to the presence of organic matter and particles in suspension. In relation to the total hardness present in the effluent, the wastewater tested at $32 \mathrm{mg} \mathrm{L}^{-1}$, alkalinity of $12 \mathrm{mg} \mathrm{L}^{-1}$, the chloride parameters were quantified at $39 \mathrm{mg} \mathrm{L}^{-1}$ and the $\mathrm{pH}$ was 5.38. Considering acidity, it is known that when the amount of the carbonic acid is the same as the total acid, then the total acid is considered as carbonic. This, however, was not noticed in our results. Thus, it is possible to conclude that there was a presence of minerals, because the analyses proposed for the total acidity corresponded to the quantity of $\mathrm{CO}_{2}$ present in the water, just like minerals. Besides that, the $\mathrm{pH}$ was below the maximum value allowed by the decree of CONAMA, Resolution 357.

To sum up, only the turbidity parameters, $\mathrm{pH}$ and color were different from the standards established by Resolution Number 357 of CONAMA for agricultural purposes. Therefore, the efficiency of the substrate, charcoal of the mesocarp, was studied in relation to the abovementioned standards, so as to verify its capacity to transform the water for reuse.

With this quantification done, the preparation of the substrate for the adsorption process 
was carried out. With the charcoal of the coconut mesocarp, the adsorption of the continuous flow column tests began. Table 1 illustrates the results.

Table 1. Results of Post Adsorption Parameters.

\begin{tabular}{|c|c|c|c|c|c|c|c|c|c|}
\hline Adsorption Time (min) & $\mathbf{0}$ & 30 & 60 & 120 & 180 & 240 & 300 & 360 & 420 \\
\hline Conductivity $\mu S / \mathrm{cm}^{2}$ & 123.0 & 163.8 & 119 & 57.9 & 56.8 & 125.4 & 93.3 & 105.1 & 101.5 \\
\hline pH & 5.38 & 6.94 & 6.98 & 6.89 & 6.84 & 7.08 & 7.00 & 6.84 & 7.10 \\
\hline Turbidity NTU & 184 & 59 & 41 & 31 & 52 & 61 & 87 & 89 & 91 \\
\hline Alkalinity $\mathbf{m g ~ L}^{-1}$ & 12 & 10 & 10 & 10 & 10 & 10 & 10 & 12 & 12 \\
\hline Total Acidity $\mathrm{mg} \mathrm{L}^{-1}$ & 30 & 20 & 20 & 10 & 10 & 10 & 10 & 10 & 10 \\
\hline Chlorides $\mathrm{mg} \mathrm{L}^{-1}$ & 39.99 & 39.99 & 24.99 & 19.99 & 19.99 & 15.00 & 10.00 & 5.00 & 10.00 \\
\hline Total Hardness $\mathrm{mg} \mathrm{L}^{-1}$ & 32 & 24 & 16 & 16 & 16 & 16 & 16 & 16 & 16 \\
\hline Calcium Hardness $\mathrm{mg} \mathrm{L}^{-1}$ & 8 & 6 & 2 & 2 & 4 & 4 & 4 & 2 & 4 \\
\hline Magnesia Hardness mg $\mathrm{L}^{-1}$ & 24 & 18 & 14 & 14 & 12 & 12 & 12 & 14 & 12 \\
\hline
\end{tabular}

These results showed that the adsorbent material was able to reduce the concentration of all parameters in the study. Time 0 refers to the raw sample and the others correspond to the amount of each in the sample collections, making it possible to evaluate the data in relation to the time of contact. As most of the parameters were within the standards, the study was based on those that had decreased more than $50 \%$ in the adsorption process.

The hardness parameter, represented by the degree of water salinity, was reduced by $50 \%$. This decrease makes the water reusable for in agriculture, because it avoids the excess of salts that cause the leaching process (dissolved salts in the ground) and pollute the superficial and underground water supplies. Cech $(2013$, p. 121) concluded that "the overflow of salts in the water may be harmful for some plants, aquatic species and for the human being... The salt soil may damage the plants and remove the humidity from the roots, reducing the capture of water and fertilizers."

According to Lenzi et al. (2012), $\mathrm{pH}$ is another factor that may influence soil composition, its control being crucial. The result of the raw water $\mathrm{pH}$ in the characterization reached a value of (5.38), out of line with the current standards in the legislation (CONAMA, 2005) which establish a minimum of 5.5 and maximum of 9.9. Thirty minutes after the adsorption, the $\mathrm{pH}$ reached the legal standard, becoming neutral after 240 minutes. This is fundamental for water reuse in agricultural fields, because the $\mathrm{pH}$ influences the dissolution of many minerals, with vital relevance for vegetation.

At the same time, the acidity was reduced by $66.6 \%$. The acidity in water is caused mainly by the presence of $\mathrm{CO}_{2}$, mineral acids and hydrolyzed salts. Acidity determination is very useful, since a sudden alteration in its normal value may influence the inorganic components present, in other words, in their solubilities (Metcalf and Eddy, 2015). These results confirmed that the studied process of adsorption would permit the use of this wastewater to irrigate agriculture.

With respect to the initial concentration of the chlorides, this started at $9.99 \mathrm{mg} \mathrm{L}^{-1}$ and, after 360 minutes of adsorption, minimized to $5 \mathrm{mg} \mathrm{L}^{-1}$, producing a reduction of $87.5 \%$. According to Luna et al. (2013) the chloride ion moves easily in a solution through irrigated water and when added in excess can change the groundwater quality standard. Inappropriate handling may result in the degradation of the soil through salinity. The adsorption treatment with coconut mesocarp charcoal added quality for its use in the watering process.

The result of the adsorption process was satisfactory and presented a slightly high percentage adsorbed (Figure 1a) given the contact time with the adsorbent substrate. Using Thomas's isotherm model, we analyzed the experimental data of this adsorption system, aiming to verify its applicability. The result obtained is able to be seen in Figure 1. 


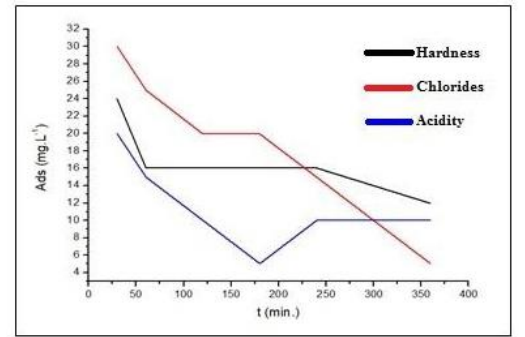

(a)

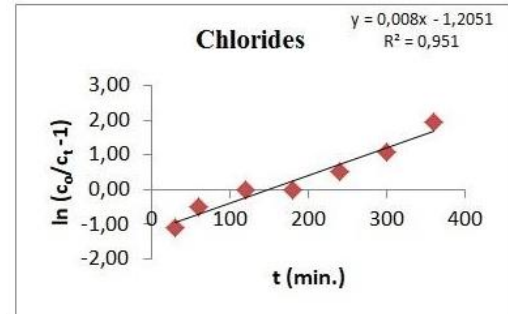

(c)

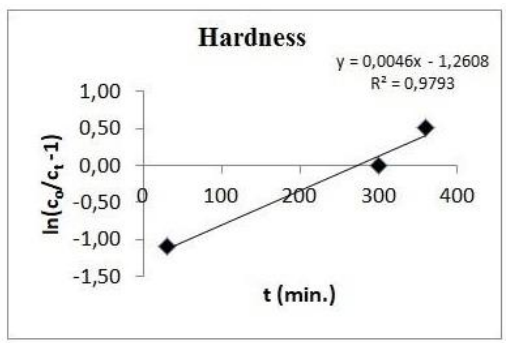

(b)

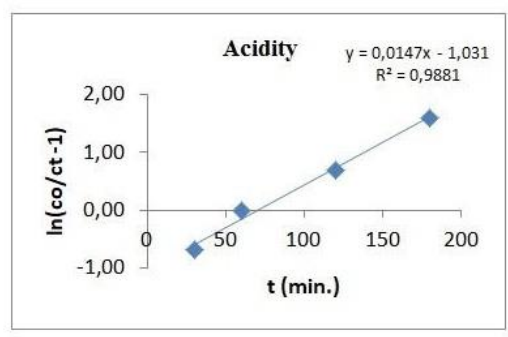

(d)

Figure 1. Adsorption and application of Thomas's isotherm for chlorides, hardness and acidity.

The Figures $(a, b, c)$ show that for the chlorides, hardness and acidity, the coefficients of correlation resulted in high values $\left(\mathrm{R}^{2}>0.95\right)$. These were acquired through the equation of the line from the respective charts, indicating that the adsorption process followed Thomas's isotherm model. This confirmed that the adsorption system in column, made on a laboratory scale, had a satisfactory performance in the removal of the parameters mentioned above.

Nevertheless, both qualitatively and quantitatively, Figure 2 shows a sudden reduction in color and turbidity. And this was only possible due to the capacity of the charcoal has to retain a great amount of suspended solids, since the adsorbent substrate is a porous material.

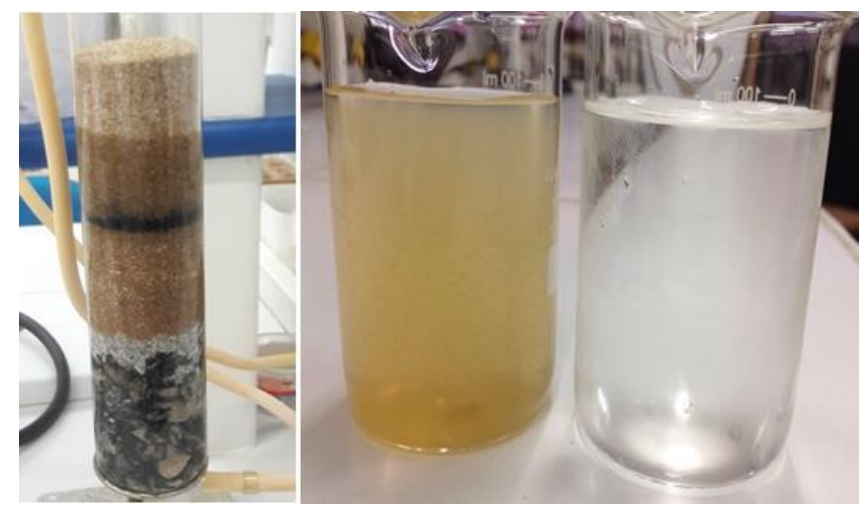

Figure 2. Implanted adsorption system and its result.

Quantitatively, the turbidity of the initial sample was high at 184 NTU, with many solid residues and suspended particles. After the column adsorption process, however, turbidity was quantified at $59 \mathrm{NTU}$ at 30 minutes of adsorption. This is a desired result, since the legislation 357 CONAMA allows a limit of 100 NTU (CONAMA, 2005).

The result of the adsorption column portrayed in Figure 2 verifies that the treatment for the effluent was satisfactory and efficient in everything, considering the quantity adsorbed according to the investigated parameters.

The adsorption capacity of the adsorbent substrate is a result of its characteristics. To identify these, an analytical study of the activated charcoal of the coco-da-baia mesocarp and the data from texture analyses, using the BET method, indicate that the adsorbent material 
presents isotherm Type I. This implies that the adsorbate distributes itself on the adsorbent surface forming a monolayer. Besides that, the presence of the isotherm implies that the adsorbent has a tendency towards chemical adsorption. Isotherms of Type I are characteristic of microporous materials, having a pore medium diameter from 0 to 20 angstroms, as is depicted at Figure 3.
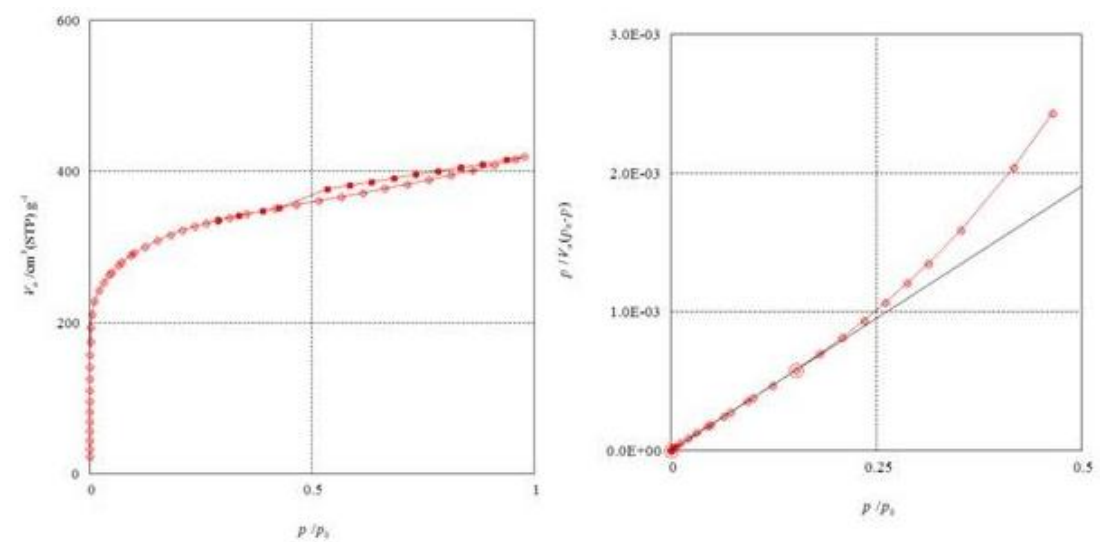

Figure 3. BET Isotherm of activated carbon of the coco mesocarp.

Medium diameter measures of the pores confirmed this hypothesis, established by the adsorption theory, since the medium diameter of the pores was around 22 angstroms. The adsorbent material presented high specific area, indicating that the adsorbent material obtained was extremely reactive, thus with a capacity for adsorption through affinity of many adsorbates.

\section{CONCLUSIONS}

In conclusion, the efficiency of the adsorbent substrate was verified, since it was able to minimize all the physical-chemical parameters, in particular, the hardness of the chlorides, acidity and $\mathrm{pH}$. The reuse strategy of the effluent under study for irrigated agriculture becomes a potential alternative for the problem of water scarcity, since the investigated adsorption technique promoted the reduction of physical and chemical parameters and added wastewater quality of ETA for Gramame. The suitability of this effluent for this purpose was proven by the correlation of the results obtained with the conditions established in the current legislation $\left(\mathrm{n}^{\circ}\right.$ 357/2005 CONAMA). Considering that the effluent was unfit for human use, the increase in water availability for agriculture was clear. Since there is a deficiency of this natural resource in the region of the Northeast where the study was carried out, this technology can be used to favorably improve the quality of the studied water. The process of column adsorption with continuous flow has already been worked on in several studies, and is especially relevant in real matrices as a proposal for the reuse of this essential resource, water.

\section{ACKNOWLEDGMENTS}

To the Federal Institute of Education, Science and Technology of Paraíba, to the CNPq for the financial investment, the Activated Carbon Laboratory of the UFPB and the LANANO.

\section{REFERENCES}

ALI, I; ASIM, M.; KHAN, T. A. Low cost adsorbents for the removal of organic pollutants from wastewater. Journal of environmental management, v. 113, p. 170-183, 2012. https://doi.org/10.1016/j.jenvman.2012.08.028 
ALI, I. The quest for active carbon adsorbent substitutes: inexpensive adsorbents for toxic metal ions removal from wastewater. Separation \& Purification Reviews, v. 39, n. 3-4, p. 95171, 2010. https://doi.org/10.1080/15422119.2010.527802

ACHON, C. L.; BARROSO, M. M.; CORDEIRO, J. S. Leito de drenagem: sistema natural para redução de volume de lodo de estação de tratamento de água. Engenharia Sanitária e Ambiental, v. 13, n. 1, p. 54-62, 2008. https://doi.org/10.1590/S141341522008000100008

AMERICAN PUBLIC HEALTH ASSOCIATION - APHA. Standard methods for the examination of water and wastewater, $21^{\mathrm{a}}$ ed. Washington, 2005.

CAMBUIM, K. B. Carvão de endocarpo de coco da baía ativado quimicamente com $\mathrm{H}_{3} \mathrm{PO}_{4}$ e fisicamente com vapor d'água: produção, caracterização e aplicações. 2009. Tese (Doutorado em Química) - Departamento de Química, UFPB, João Pessoa, 2009.

CECH, T. V. Recursos hídricos: história, desenvolvimento, política e gestão. Rio de Janeiro: LTC, 2013.

CONSELHO NACIONAL DO MEIO AMBIENTE (Brasil). Resolução n 357 de 17 março de 2005. Diário Oficial [da] União: seção 1, Brasília, DF, n. 53, p. 58-63, 18 mar. 2005.

DALFOVO, M. S.; LANA, R. A.; SILVEIRA, A. Métodos quantitativos e qualitativos: um resgate teórico. Revista Interdisciplinar Científica Aplicada, v. 2, n. 4, p. 01-13, 2008.

DE FRANCO, M. A. E. et al. Diclofenac removal from water by adsorption using activated carbon in batch mode and fixed-bed column: isotherms, thermodynamic study and breakthrough curves modeling. Journal of Cleaner Production, v. 181, p. 145-154, 2018. https://doi.org/10.1016/j.jclepro.2018.01.138

DO NASCIMENTO, R. F. et al. Adsorção: aspectos teóricos e aplicações ambientais. Fortaleza: Imprensa Universitária, 2014. 256p.

LENZI, E. et al. Introdução a química da água. São Paulo: Freitas Bastos, 2012.

LUNA, N. R. S. et al. Dinâmica do nitrato e cloreto no solo e a qualidade das águas subterrâneas do distrito de irrigação Baixo Acaraú, CE. Revista Agro@mbiente, v. 7, n. 1, p. 53-62, 2013. http://dx.doi.org/10.18227/1982-8470ragro.v7i1.1042

MATSUBARA, M. E.; COELHO, L. H. G. Evaluation of the Use of Fly Ash as a Low Cost Technology for Phosphorus Removal in Wastewater Treatment. Revista Ambiente \& Água, v. 13, n. 3, 2018. http://dx.doi.org/10.4136/ambi-agua.2166

METCALF, L.; EDDY, H. P. Tratamento de efluentes e recuperação de recursos. Rio de Janeiro: McGraw Hill Brasil, 2015.

MONTEIRO, M. S. et al. Wood (Bagassa guianensis Aubl) and green coconut mesocarp (cocos nucifera) residues as textile dye removers (Remazol Red and Remazol Brilliant Violet). Journal of environmental management, v. 204, p. 23-30, 2017. https://doi.org/10.1016/j.jenvman.2017.08.033

SILVA, R. T. S. et al. Simulação numérica e ensaios experimentais da remoção de Fe (III) da água para utilização nas indústrias alimentícias. Engenharia Sanitária Ambiental, v. 20, n. 4, p. 653-663, 2015. https://dx.doi.org/10.1590/S1413-41522015020040112681 
SOUSA NETO, V. O. Modificação química da casca do coco bruto (Cocos Nucifera) para remoção de Cu (II) de Efluente Sintético e Industrial: estudo de isoterma de adsorção, cinética e coluna de leito fixo. 170 f. 2012. Tese (Doutorado em Engenharia Civil) Departamento de Engenharia Hidráulica e Ambiental, Universidade Federal do Ceará, Fortaleza, 2012.

TELLES, D. D.; COSTA, R. H. P. G. Reúso da água: conceitos, teorias e práticas. 2. ed. São Paulo: Blucher, 2010.

YANG, J.; YU, M.; CHEN, W. Adsorption of hexavalent chromium from aqueous solution by activated carbon prepared from longan seed: Kinetics, equilibrium and thermodynamics. Journal of industrial and engineering chemistry, v. 21, p. 414-422, 2015. https://doi.org/10.1016/j.jiec.2014.02.054

YAUMI, A. L.; BAKAR, MZ Abu; HAMEED, B. H. Melamine-nitrogenated mesoporous activated carbon derived from rice husk for carbon dioxide adsorption in fixed-bed. Energy, v. 155, p. 46-55, 2018. https://doi.org/10.1016/j.energy.2018.04.183 